\title{
MAFF in a stew over food research plans
}

[LONDON] Food safety researchers in Britain are locked into a bitter controversy over plans to restructure several laboratories. The main trigger has been a proposal by the Ministry of Agriculture, Fisheries and Food (MAFF) to close its main food safety laboratory in Norwich, and to relocate staff to the newly built Central Science Laboratory (CSL) 200 miles north in York.

These proposed changes coincide with uncertainty about the future of two other food laboratories - in Reading and in Norwich - that are part of the Institute of Food Research, run by the Biotechnology and Biological Sciences Research Council (BBSRC). An internal review of their operation suggested merging the two laboratories on one site.

MAFF's plans for the Norwich laboratory are being vigorously opposed by its scientists and many independent food researchers, as well as by consumer groups. Representatives of all three say they have difficulty in understanding the ministry's haste in ordering the changes, given that responsibility for food safety will soon fall into the hands of an independent Food Standards Agency.

MAFF officials say the move is needed to fill laboratory space at York — half of which lies vacant because of cuts to the ministry's research budget. The empty space has to be accounted for as all government departments now have to pay rent on property they own. "We can't afford to have empty buildings," say the officials.

The move is also being officially justified on the grounds that the average cost per scientist at York will be less than at Norwich. The York laboratory was built in mid-1996. The aim was to collect under one roof MAFF's 14 smaller food research laboratories. The new laboratory is engaged primarily in producer-oriented research, such as research into pesticides.

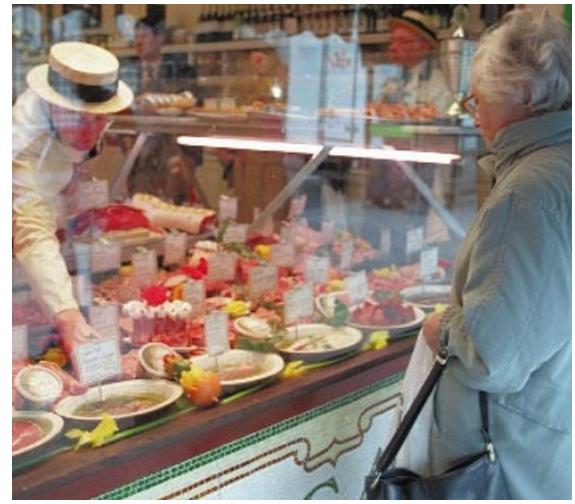

The front line: a succession of 'food scares' has made food safety research a contentious issue.

One option being considered by ministers is to close the BBSRC Reading site and move its work to the vacant MAFF building in Norwich - if the MAFF Norwich operation closes.

The local member of parliament, Charles Clarke (Labour, Norwich South), is supporting MAFF scientists in their bid to keep the laboratory in his constituency. He has tabled parliamentary questions to the food minister, Jeff Rooker, asking for a detailed breakdown of the relative costs of Norwich and York. "I haven't received any answers as yet," he says.

Clarke says he also intends to raise questions about the fate of the 'missing millions' - a reference to the mismatch between the

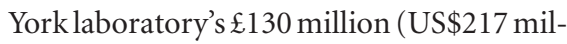
lion) building costs and its present value of $\mathfrak{£} 87$ million.

Most researchers at Norwich are bitterly opposed to the move. But they fear that a decision may already have been made, in which case many — including senior staff will probably resign. An offer of a management buyout is understood to have been rejected by civil servants. And the laboratory's director, John Gilbert, a known critic

\section{Novartis goes public with fraud dismissal}

[BASEL] The Swiss pharmaceutical industry appears to be taking a lead from public research institutions in Germany in making information about potentially embarrassing situations involving scientific fraud more readily available to the public.

Last week, Novartis reported that a scientist had been dismissed from its research department in Basel. In a recent routine internal investigation, the company found the researcher had continuously manipulated preclinical results in a cancer research project.

The research project is being conducted with California-based Isis Pharmaceuticals, and includes testing anticancer compounds on xenografts of human tumours in animals. A spokesman says that this is the first such case to have emerged since Novartis was created two years ago by the merger of two large Swiss drug companies, Ciba and Sandoz.

The company is planning further investigations to determine what it describes as the "total damage" caused by the scientist. But it says it is not considering any additional routine control of researchers. Novartis and Isis will continue the joint project. "We have sufficient data and tests which are unaffected by the incident," says the spokesman. of the plans, has been moved to a new MAFF post in London. He was out of the country and so unavailable for comment when this article went to press.

Earlier this month, Richard Packer, MAFF's permanent secretary and the department's highest-ranking civil servant, met staff at Norwich to explain the rationale behind the relocation plans. "Most at that meeting made clear their total opposition to the plans," says one scientist who declines to be named.

"These plans make no sense," says another scientist. "Norwich has made a name for itself as a centre for research into the safety of chemicals in food. Destroying such a facility should not be the answer to the financial problems of York."

The move is also being questioned by food safety experts and consumer groups, which argue that the ministry should be scaling down its direct involvement in food safety research, given that it will no longer be responsible for food safety following the government's decision to create an independent standards agency (see Nature 389, 109; 1997).

MAFF is meant to be withdrawing from the process of setting food safety research priorities even before the food standards agency is set up (see Nature 391, 313; 1998). "Any decision on the fate of the Norwich labs ought to be taken by the food agency, rather than MAFF," says David McWeeny, a former director of the Norwich laboratory.

Erik Millstone, a food policy researcher at the Science Policy Research Unit at the University of Sussex, agrees. He acknowledges that the agency will need a dedicated laboratory that can provide "firefighting" services in response to potential food scares. But the agency will not want to be permanently tied to one research facility as it will want to commission research from laboratories independent of government. "The agency needs the freedom to commission research whenever and wherever it likes."

But a MAFF official points out that the government only wants the agency to control

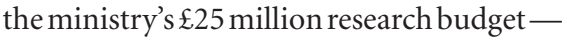
not the actual research laboratories. "The agency will have the freedom to decide on research [priorities]. But it cannot make decisions about a facility it does not own."

Consumer groups are concerned about the implications of Norwich's consumeroriented research being housed alongside existing producer-oriented work at the CSL. Julie Sheppard, senior public affairs officer at the Consumers' Association, says that the move would be in conflict with the government's stated promise to place food safety research away from the influence of the food industry.

EhsanMasood 